\title{
Sejarah Hubungan Masyarakat Melayu dan Bugis Sebagai Asas Pembinaan Naratif dalam Novel Sasterawan Negara Arena Wati
}

\author{
NORHAYATI AB. RAHMAN \\ Akademi Pengajian Melayu, Universiti Malaya, 50603 Kuala Lumpur, Malaysia. \\ yati@um.edu.my
}

\begin{abstract}
Abstrak Hubungan serumpun antara masyarakat Melayu dan Bugis telah berlangsung semenjak kurun ke-18 seperti yang dipaparkan dalam teks Salasilah Melayu dan Bugis serta Tuhfat al-Nafis karya Raja Ali Haji. Teks-teks ini telah memerihal peranan Bugis dalam pergelutan politik Melayu pada ketika itu. Di samping itu, ikatan perkahwinan dan penglibatan serta kedudukan dalam politik khususnya telah membawa kepada proses sosialisasi dan asimilasi yang berterusan antara Melayu-Bugis sehingga kini. Selain berdasarkan penceritaan dalam teks-teks sastera Melayu tradisional yang banyak memaparkan tentang hubungan dua hala tersebut, lakaran tersebut juga dijadikan sebagai asas pembinaan naratif dalam novel-novel Sasterawan Negara Arena Wati. Justeru, tulisan ini akan membincangkan dan memperlihatkan bagaimana dan sejauh manakah hubungan serumpun antara dua bangsa ini diangkat dalam naratif garapan Sasterawan Negara Arena Wati melalui novel-novelnya Sandera (1971), Sudara (1994), Warna Sukma Usia Muda (2005) dan Rindu Aroma Padi Bunting (2012). Selain itu, tulisan ini juga akan menampilkan impak hubungan tersebut ke atas situasi hubungan semasa antara Malaysia dan Indonesia pada hari ini.
\end{abstract}

Kata kunci: Serumpun, Melayu-Bugis, sastera, Arena Wati, novel

Abstract Relations between the Malays and Bugis have lasted since the $18^{\text {th }}$ century as shown in the Salasilah Melayu dan Bugis and Tuhfat al-Nafis by Raja Ali Haji. These texts describe the role of Bugis in Malay political struggle at that time. In addition, the bond of marriage and political involvement in particular has led to a process of socialization and assimilation which continues between the Malay-Bugis until present. Apart from the narrative in the texts of traditional Malay literature which significantly highlights the bilateral relationship, the sketch is also used as the building blocks of the narrative in the novels of the National Laureate Arena Wati. Thus, this paper 
attempts to discuss and demonstrate how and to what extent the relationship between the two nations is lifted in the narrative of the National Laureate Arena Wati through his novels such as Sandera (1971), Sudara (1994), Warna Sukma Usia Muda (2005) and Rindu Aroma Padi Bunting (2012). In addition, this paper also shows the impact of those relationships on the state of current relations between Malaysia and Indonesia.

Keywords: Cluster/stock, Malay-Bugis, literature, Arena Wati, novel

\section{PENGENALAN}

Dari segi etimologi, perkataan sejarah berasal daripada perkataan Arab, iaitu Syajaratun yang bermaksud 'pohon'. Istilah history pula merupakan terjemahan daripada perkataan Yunani, historio yang membawa makna satu penyelidikan. Menurut Herodotus, yang dikenali sebagai 'Bapa Sejarah', sejarah ialah satu kajian untuk menceritakan satu kitaran jatuh bangunnya seseorang tokoh, masyarakat dan peradaban. Aristotle pula menyatakan, sejarah merupakan satu sistem yang mengira kejadian semula jadi dan tersusun dalam bentuk kronologi, serta pada masa yang sama, sejarah adalah peristiwa-peristiwa masa lalu yang mempunyai catatan, rekod atau bukti yang kukuh. Menurut R. G. Collingwood, sejarah ialah sejenis bentuk penyelidikan atau suatu penyiasatan tentang perkara-perkara yang telah dilakukan oleh manusia pada masa lampau (1966: 2). Sementara itu, Sidi Gazalba cuba menggambarkan sejarah sebagai masa lampau manusia dan persekitarannya yang disusun secara ilmiah dan lengkap, meliputi urutan fakta masa tersebut dengan tafsiran dan penjelasan yang memberi pengertian dan kefahaman tentang apa yang berlaku (1966: 11).

Kamus Dewan telah mentakrifkan sejarah sebagai asal usul, keturunan, salasilah, peristiwa yang benar-benar berlaku pada waktu yang lampau, kisah, riwayat, tambo, tawarikh dan kajian atau pengetahuan mengenai peristiwa yang telah berlaku (1966:1040). Pengertian sejarah boleh dilihat dari tiga dimensi, iaitu epistemologi (kata akar), metodologi (kaedah sesuatu sejarah itu dipaparkan) dan falsafah atau pemikiran peristiwa lalu yang dianalisa secara teliti untuk menentukan sama ada ia benar atau tidak (Collingwood, 
1966: 39). Kamus Besar Bahasa Indonesia menyebut sejarah sebagai "salsilah; asal usul (keturunan), kejadian dan peristiwa yang benar-benar terjadi pada masa lampau; ilmu pengetahuan atau huraian tentang peristiwaperistiwa dan kejadian-kejadian yang benar-benar terjadi di masa lampau" (1988:794). Sementara Kamus Bahasa Melayu Nusantara menyatakan karya kreatif merujuk kepada "hasil seni, tulisan dan sebagainya; ciptaan pengarang yang menjadi rujukan peneliti sastera” (2003:1194).

\section{SEJARAH HUBUNGAN MELAYU BUGIS SEBAGAI ASAS PEMBINAAN NARATIF DALAM NOVEL SASTERAWAN NEGARA ARENA WATI}

Sejarah telah mencatatkan bahawa hubungan serumpun antara Melayu dan Bugis [ ${ }^{1}$ ] telah berlangsung secara signifikan pada kurun ke-17 dan ke-18 dengan kedatangan awal orang Bugis ke Tanah Melayu yang menetap di sekitar Linggi, Kuala Selangor dan Johor-Riau. Gambaran tersebut dapat dikesan dalam teks Salasilah Melayu dan Bugis serta Tuhfat al-Nafis karya Raja Ali Haji. Melalui teks-teks tersebut, Raja Ali Haji memerihal akan kehadiran dan peranan Bugis dalam pergelutan politik Melayu pada ketika itu. Leonard Y. Andaya menyebut bahawa dalam tempoh 1699 hingga tahun 1728, Tuhfat al-Nafis harus dianggap sebagai suatu dokumen yang cuba membuktikan dan mengesahkan campur tangan orang Bugis di alam Melayu dan khususnya di dalam Kerajaan Johor (1987: 10). Sejarah juga mencatatkan bahawa terdapat banyak sebab yang membawa kepada penghijrahan Bugis ke seluruh Nusantara termasuk ke negeri Melayu.

Christian Pelras dalam buku The Bugis (1997) menyatakan berlakunya penghijrahan besar-besaran pada abad ke-17 dan awal abad ke-18 dalam kalangan masyarakat Bugis Sulawesi Selatan kerana berasa tertekan. Mereka berhijrah ke Sumbawa, Lombok, Bali, Jawa, Sumatera, Borneo dan Semenanjung Tanah Melayu. Kebanyakan masyarakat Bugis memilih Johor sebagai destinasi penghijrahan. Andi Ima Kesuma dalam bukunya Migrasi dan Orang Bugis pula menyebut "migrasi pada hakikatnya termasuk salah satu daripada produk perang. Selain dari itu juga merupakan produk sosial terhadap suatu sistem pemerintahan yang tidak memberi nuansa kebebasan bagi rakyat-baik sifatnya ekonomis maupun non-ekonomis" (2004: 29). Menurut 
beliau lagi, penglibatan orang Bugis dengan orang Melayu berlangsung lama sejak abad XVII di Kepulauan Nusantara sebagai akibat perang Syarikat Hindia Timur/Vereenigde Oost-Indische Campagnie (VOC)-Makassar, terutama setelah jatuhnya Benteng Somba Opu serta direbutnya Tosara, ibu kota Kerajaan Wajo, sekutu Kerajaan Makassar dan Kerajaan Luwu. Dalam penelusuran proses migrasi ke Johor Malaysia, di awal abad ke-17, tersebut antara mereka nama-nama seperti Opu Daeng Parani, Opu Daeng Menambun, Opu Daeng Marewa, Opu Daeng Chelak dan Opu Daeng Kamase. Kelima bersaudara tersebut adalah anak dari Opu Daeng Rilakka yang dalam Sejarah Tanah Melayu disebutkan bahawa tahun 1861, orang Bugis telah membuka negeri Kuala Selangor dan Kuala Kelang (Andi Ima Kesuma, 2004:). ${ }^{2}$

Secara umumnya, konteks hubungan Melayu-Bugis telah terjalin melalui pelbagai kaedah, terutama melalui penglibatan serta kedudukan dalam politik, perdagangan, perkahwinan yang seterusnya membawa kepada proses sosialisasi dan asimilasi yang berterusan antara Melayu-Bugis sehingga hari ini. Berdasarkan catatan sejarah, secara umumnya konteks hubungan Melayu-Bugis dapat dibincangkan dalam beberapa aspek utama. Kesemua aspek ini memberi implikasi yang besar ke atas sejarah hubungan Melayu serumpun, sekali gus mewarnai sosiopolitik dan budaya pada hari ini. Antara aspek tersebut ialah;

1. Hubungan politik

2. Hubungan perkahwinan

3. Hubungan perdagangan

4. Hubungan sosiobudaya

Hubungan Melayu-Bugis dan suku-suku kaum lain yang merupakan penduduk di sekitar Kepulauan Melayu selain banyak dipaparkan dalam catatan sejarah, ia juga mendominasi naratif dalam penciptaan novel-novel Sasterawan Arena Wati. Gambaran yang dipaparkan tersebut kebanyakannya adalah berasaskan kepada fakta-fakta dalam penulisan pensejarahan Melayu. Menurut Leonard Y. Andaya, Babad Siak, Tuhfat al-Nafis dan Peringatan Sejarah Negeri Johor dapat dianggap sebagai dokumen yang memaparkan kisah tentang peranan yang masing-masing dimainkan oleh orang Minangkabau, Bugis dan orang Melayu Johor pada penghujung kurun 
ke tujuh belas dan pada bahagian pertama kurun ke lapan belas (1987:14). Justeru, teks-teks tersebut dapat dianggap sebagai penulisan sejarah yang memapar dan memperlihatkan sejauh mana kelangsungan hubungan antara dua bangsa ini di alam Melayu, serta kesan daripada hubungan tersebut ke atas kedua-dua belah pihak. Selain berdasarkan penceritaan dalam teks-teks sejarah dan sastera Melayu tradisional yang banyak memaparkan tentang hubungan dua hala tersebut, lakaran tersebut juga dijadikan sebagai asas pembinaan naratif dalam kebanyakan novel Sasterawan Negara Arena Wati.

\section{Hubungan Politik}

Konteks politik $\left[{ }^{3}\right]$ yang melibatkan hubungan Melayu-Bugis seperti yang digambarkan teks Salasilah Melayu dan Bugis serta Tuhfat al-Nafis karya Raja Ali Haji jelas memerihalkan peranan Bugis dalam pergelutan politik Melayu pada ketika itu. Perebutan kuasa pemerintahan antara raja-raja di negeri-negeri Tanah Melayu pada ketika itu membuka ruang dan peluang kepada kemasukan campur tangan dan pengaruh kuasa Bugis di negerinegeri Melayu. Bermula dengan bantuan peperangan, akhirnya memberi kuasa kepada mereka dalam urusan pentadbiran. Contohnya, penglibatan putera Bugis, Opu Daeng Parani dan saudara-saudaranya dalam membantu mengembalikan takhta Raja Johor, Raja Sulaiman yang dirampas oleh Raja Kecil dari Minangkabau. Sebagai balasan atas pertolongan tersebut, Opu Daeng Marewah dilantik sebagai Yamtuan Muda dalam Kerajaan JohorRiau-Lingga.

Sementara di Kedah, penglibatan Bugis dalam politik Kedah bermula apabila Raja Kedah meminta bantuan daripada Opu lima bersaudara untuk menjadikannya Yamtuan di negeri Kedah setelah direbut oleh adiknya menjadi Yamtuan Muda. Opu Daeng Parani bersetuju dengan syarat semua orang Bugis, Makassar dan Mandar diletakkan di bawah kuasa perintahnya. Mereka membantu menumpaskan Raja Kedah muda dalam peperangan, dan kejayaan beliau menyebabkan beliau telah dikahwinkan dengan adik Raja Kedah tua serta melahirkan seorang puteri. Di Selangor, Daeng Chelak pula mendapat tempat di Selangor apabila membantu menewaskan musuhnya, sehingga akhirnya anaknya, Daeng Lumu (1742-1778) dilantik menjadi Yang Dipertuan Kelang yang pertama. Beliau adalah Raja Selangor yang 
pertama bersemayam di atas Bukit Malawati. Hal yang sama kemudian telah mendapat tempat istimewa dalam proses kreatif serta dijadikan sebagai asas pembinaan naratif oleh Arena Wati dalam penulisan novel-novelnya.

Melalui novel Sudara (1994) misalnya, pengarang menampilkan subjek sejarah sebagai tema bagi mengungkapkan pemikiran melalui watakwatak utamanya, iaitu Raja Hamidah dan temannya Sallehudin yang masingmasing sedang dalam proses penulisan tesis bagi penyelidikan sejarah asal usul keluarga mereka. Antara lain, gambaran tentang konflik hubungan Melayu-Bugis mengikut kajian mereka diperlihatkan seperti berikut;

“Kenapa Raja Haji berbuat begitu?” "Kerana Riau sudah tidak mampu membina armada. Belanjanya terlalu besar dan perlukan laksamana yang mahir. Bugis dan Orang Laut yang mahir membina armada dan perang laut sudah tinggalkan Riau. Bugis yang pindah ke Selangor dan Linggi sudah patah hati kepada Riau" (Sudara, hlm. 187).

"Sebab leka candu mereka tidak tau buat kerja. Dahulu mereka tidak suka Bugis banyak ladang. Tidak suka Bugis dan Orang Laut pandai buat bahtera dan jadi saudagar. Dulu siapa beri mereka makan? Kami! Dulu mereka tidak perlu berhutang. Sekarang? Kerana hutang tidak mampu mereka bayar, maka Belanda masukkan Cina jadi peladang, pedagang, saudagar, nelayan. Itu semua untuk jadi pengganti Bugis dan Orang laut, kerana mereka sendiri tidak tau buat kerja" (Sudara, hlm. 167).

Dua gambaran di atas memperlihatkan bagaimana pengarang mencitrakan Bugis dengan kemahiran mereka yang luar biasa dalam teknologi pembuatan dan pembinaan armada, berdagang dan juga dalam peperangan. Pemaparan ini secara tersirat memperlihatkan hasrat dan usaha pengarang Arena Wati untuk mengangkat imej Bugis, dengan cara memetik sebahagian daripada fragmen sejarah yang berlaku dalam hubungan Melayu-Bugis sebagai sumber penulisan novelnya. Dengan menampilkan watak-watak berketurunan Bugis yang menetap di Malaysia 
pada hari ini, sekali gus sebagai pengkaji dan penulis tesis di Universiti Kebangsaan Malaysia (UKM), Bangi dalam bidang sejarah, pengarang berpeluang membawa pembaca untuk kembali kepada sejarah keagungan silam. Manuskrip 'salsilah' catatan nenek moyang yang diwarisi daripada satu generasi ke satu generasi dan peninggalan artifak berbentuk belahan 'caping' $\left({ }^{4}\right)$ yang diwarisi oleh ibu Raja Hamidah, iaitu Dr. Raja Hamisah daripada nenek moyangnya, Daya Mulli, yang diwarisi pula daripada nenek moyangnya. Susur galur pewarisan ini membawa kepada perkembangan plot dan naratif novel Sudara, mempertemukan orang Bugis dan Melayu dalam sejarah dan implikasinya pada masyarakat pada hari ini. Melalui novel Sudara juga, pengarang menggambarkan secara tidak langsung tentang jurai keturunan keluarga Raja Hamidah yang berasal dari Makasar dan kemudian sebahagiannya berhijrah sehingga ke Kemboja, Ayuthia dan kemudian sebahagiannya menetap di Selangor.

Gambaran tentang penglibatan hubungan politik antara Melayu-Bugis juga dapat dikesan pada novel yang sama apabila pengarang menggambarkan situasi kekacauan di Riau pada ketika itu, lantaran serangan daripada Siak. Kemelut politik yang berlaku telah mendorong Sultan Riau telah menghantar utusan ke Selangor bagi memujuk Daeng Kemboja agar kembali ke Riau seperti yang dapat dikesan pada catatan berikut;

"Sultan Riau menangis mengirim utusan ke Selangor memujuk Daeng Kemboja kembali ke Riau. Selangor, Linggi dan Rembau yang sudah membebaskan diri daripada Johor-Riau makin berkembang ekonominya kerana saudagar dan peladang dari Riau bertumpu ke sana. Ketika Daeng Kemboja tiba kembali ke Riau - dengan hati enggan - dia menangis menyaksikan penderitaan penduduk. Dia kesal kerana Riau tergadai” (Sudara, hlm. 160).

Pada tahun 1785, ketika Belanda menguasai Riau selepas kemangkatan Daeng Kemboja dan kekalahan Raja Haji serta Raja Jaafar menjadi Yamtuan, lantas telah memajakkan Riau kepada Belanda tanpa berbincang dengan batin-batin Orang Laut. Ketika itu, Yamtuan Muda dan pembesar negeri, kerabat sultan semuanya hidup bergantung kepada saraan Belanda. Sementara Orang Laut dan orang Bugis yang sebelumnya membangunkan ekonomi dan kebesaran Kerajaan Riau-Johor telah disingkirkan. Memandangkan mereka tidak ingin terlibat dalam proses 'penjualan negara,' mereka telah 
meminggirkan diri dan menyaksikan bagaimana Belanda membawa masuk orang-orang Cina untuk mengambil alih tugas di ladang-ladang yang sebelumnya dilaksanakan oleh orang Bugis.

Demikian sebahagian daripada gambaran sejarah penglibatan Bugis dalam kancah politik di negeri Melayu yang dicitrakan oleh pengarang Arena Wati melalui novel Sudara. Pemaparan tersebut memperlihatkan bagaimana penglibatan Bugis dalam aspek politik di negeri Melayu yang akhirnya mendekatkan mereka dengan masyarakat setempat, sekali gus menjadi sebahagian daripada penduduk dan pemimpin. Malah, masyarakat Melayu-Bugis (berketurunan Bugis) juga telah menjadi 'orang penting' dalam pentadbiran di Malaysia sehingga hari ini. Selain daripada itu, gambaran hubungan Melayu-Bugis dalam politik juga dapat dilihat dalam konteks penghijrahan orang Melayu ke Makassar, yang kemudian berkahwin dengan penduduk tempatan di sana. Hal ini banyak dimuatkan dalam novelnya berjudul Sandera (1971), yang memaparkan kisah perjuangan penduduk peribumi menentang penjajah sehingga membawa mereka ke penjara. Novel ini menceritakan kisah kebangkitan rakyat di Nusantara menentang penjajahan dari pihak luar. Kandungan novel ini juga mengandungi panduan dan nasihat kepada mereka yang hidup selepas merdeka agar menghargai dan memahami kemerdekaan yang telah diperjuangkan oleh para pemimpin terdahulu.

Novel ini memaparkan kisah kebangkitan rakyat di Nusantara menentang penjajahan dari pihak luar. Mesej novel ini juga mengandungi panduan dan nasihat kepada mereka yang hidup selepas merdeka agar menghargai dan memahami kemerdekaan yang telah diperjuangkan oleh pemimpin terdahulu. Melalui karya ini, pembaca telah dibawa melawat watak utama, Busad yang berada di sebuah penjara di Karebosi, Makassar sebelum dibawa ke penjara Tanah Merah, Indonesia. Busad seperti yang difahami melalui novel ini merupakan anak Makassar yang mempunyai bapa, Ibrahin yang berasal dari Terengganu. Hal ini dijelaskan pengarang dalam paparan berikut:

"Busad juga ingat, keluarga ibunya orang Makassar sejati. Dan walaupun orang Makassar terkenal dengan sikap suka membunuh orang, tapi bukan dengan gila-gilaan begitu. Mereka membunuh 
untuk mempertahankan marwah. Jadi bukan untuk tidak apa-apa. Dan ayahnya, yang sudah mati akibat sakit pening kepala setelah perang dunia pertama, terkenal orang baik. Ayah Busad orang alim. Memang ayahnya bukan orang Makassar, bukan orang Bugis, dia orang datang dari Tanah Melayu. Pun datangnya ke Makassar bukan untuk tidak apa-apa. Ayahnya meninggalkan Tanah Melayu kerana penentangannya kepada politik raja yang selalu mengalah kepada Inggeris, dan sikap beku dari mufti yang terlalu kaku menghadapi zaman bagi ugama Islam" (Sandera, hlm. 7).

Petikan di atas seolah-olah membenarkan anggapan bahawa pemimpin Kesatuan Melayu Muda (KMM), Ibrahim Yaakob yang dilahirkan di Pahang dan dikatakan berketurunan Bugis itu mempunyai susur galur dari Sulawesi Selatan, seperti yang dimaksudkan dalam novel ini. Ciptaan watak Busad di dalam novel ini ternyata mendapat inspirasi daripada tokoh Ibrahim Yaakob sendiri sebagai seorang pemimpin Kesatuan Melayu Muda. Namun, yang penting dalam konteks pembicaraan ini ialah novel ini jelas memaparkan hubungan politik antara Melayu-Bugis yang diasaskan pada sumber sejarah yang sedia wujud sejak sekian lama. Sekali gus, pernyataan ini membuktikan Arena Wati menggerakkan naratifnya, menghidupkan watak-watak serta memaparkan subjek dan pemikiran yang berhubung dengan konteks Melayu-Bugis.

\section{Hubungan Perdagangan}

Andi Zainal Abidin Farid dalam Persepsi Orang Bugis Makassar tentang Hukum dan Dunia Luar (1993) menjelaskan kedatangan orang Bugis, Makassar, Mandar ke negeri Melayu tujuannya untuk berdagang, namun tidak mustahil kalau ada sebagian secara terpaksa, di saat kekuarangan makanan atau modal, mereka melakukan pembajakan di laut (1993: 2). Malah pada tahun 1424 - 1444, Melaka mulai menjadi sebuah pelabuhan antarabangsa yang dikunjungi oleh para pedagang dari berbagai negara, terutama dari Portugis. Catatan Portugis menunjukkan bahawa masyarakat Sulawesi Selatan dari zaman nenek moyang mereka telah banyak mengembara mengharungi lautan menuju ke berbagai negara kerajaan tetangga, termasuk ke Tanah Melayu. Penglibatan dan hubungan Melayu-Bugis dalam aspek perdagangan dan politik di alam Melayu ini turut diperincikan Arena Wati dalam novel Sudara apabila beliau mencatatkan; 


\begin{abstract}
"Walaupun Melaka dikuasai Portugis selama 130 tahun, tetapi saudagar dan armada dagang bangsa Melayu dari Tanah Melayu masih kuat kerana dapat bergabung dengan saudagar dan armada dagang Makasar dan berpengkalan di Gowa untuk menguasai perdagangan rempah ratus dari Maluku dan seluruh Pulau Kalimantan, sehinggalah Makasar dikalahkan Belanda pada tahun 1667" (Sudara, hlm. 306).
\end{abstract}

Gambaran ini menunjukkan keupayaan dan kejayaan orang Melayu dalam bidang perdagangan telah diperteguhkan dengan adanya kerjasama serta bantuan saudagar dan armada Makasar yang memang terkenal sebagai pedagang yang hebat di alam Melayu. Hal yang demikian itu adalah amat wajar memandangkan kebanyakan orang Bugis diasuh dengan ilmu berdagang, belayar dan merantau semenjak mereka masih berusia muda. Falsafah merantau bagi masyarakat Bugis adalah berbekalkan konsep 'tiga ujung,' iaitu ujung lidah (diplomasi), ujung badik (perang) dan ujung kemaluan (perkahwinan) (Andi Ima Kesuma, 2004: 5 - 6). Dengan berpegang kepada konsep tersebut, maka mereka membina kekuatan dan menebar keturunan di seluruh Nusantara, malah sehingga ke dunia Eropah. Dalam kegiatan perdagangan orang Bugis ini, pengarang Arena Wati menggambarkan bahawa sejak usia belasan tahun mereka sudah dilatih untuk memahirkan diri, seperti contoh petikan berikut:

\begin{abstract}
"Anak lelakinya, Raja Usman Plurang itu, dalam usia belasan tahun sudah jadi kelasi dalam armada dagang. Dia diajar ilmu dan etika nakhoda oleh Patappak Daeng Mantek, dan berpengkalan di Kampong Som" (Sudara, hlm. 307).
\end{abstract}

Melalui Warna Sukma Usia Muda pula, pengarang memaparkan kisah pemuda bernama Abdul Rahim dari Makasar, menghabiskan sebahagian besar usianya dengan merantau dari satu daerah ke satu daerah yang lain di seluruh alam Melayu. Berdasarkan teks tersebut, watak utama, iaitu Abdul Rahim dan anak-anak kapalnya keluar belayar dan membina kehidupan baharu, di daerah baharu antara lain disebabkan oleh situasi politik yang tidak kondusif pada zaman tersebut. Pendudukan penjajah Belanda di Indonesia menyebabkan ramai penduduk tempatan keluar dari daerah asal dengan pelbagai alasan. Dalam hal ini, Andi Ema Kesuma menyebut: 
"Terjadinya migrasi keluar secara besar-besar tidak dapat dipisahkan dengan akibat Perang VOC-Makasar pada tahun 1667, suatu bentuk perang yang unik lagi dahsyat, tak ada taranya dengan perang kolonial lainnya yang pernah terjadi pada masa kekuasaan VOC/Belanda di Kepulauan Nusantara" (Warna Sukma Usia Muda, hlm. 58).

Pengarang Arena Wati sekeluarga turut menghadapi tekanan daripada pihak penjajah Belanda yang telah merampas segala harta benda milik keluarganya, termasuk barang-barang kebesaran keluarga dari rumah pusaka mereka turut dirampas. Selain merampas harta benda milik penduduk, ramai keluarganya dari Jeneponto dan Ujung Pandang yang sedang belajar di sekolah menengah telah dipaksa melucut pakaian sekolahnya dan diganti dengan pakaian seragam tentera Belanda, bertopi baja, dengan alasan bahawa sekarang Inlanders mesti mempertahankan negerinya sendiri (2010: 66). Situasi zaman penjajahan tersebut merupakan faktor dalaman di tempat asal, iaitu Makassar yang tidak kondusif bagi Abdul Rahim. Justeru menurut watak Abdul Rahim dalam karya ini (yang mewakili susuk Arena Wati dalam realiti) menyatakan, "keadaan inilah yang menyebabkan saya terus jadi pelaut" (2010: 72).

Gambaran pengalaman sebenar pengarang Arena Wati dipaparkan melalui watak-watak dalam penulisannya. Umpamanya watak Daeng Nanjeng (rakan kongsi ayah Abdul Rahim), Daeng Massuk, Jalle (timbalan jurumudi) dan Basaru (jurubatu kanan), Hamad (ketua kelasi) dan puluhan anak-anak kapalnya merantau untuk tujuan perdagangan (ekonomi). Pada 26 Julai beliau mengepalai kapal Sukma Bayu keluar dari Kalibaru di Jawa Timur dengan muatan yang terdiri daripada barang makanan seperti cili kering (bahan penting dalam rempah ratus), beras dan pulut yang akan dibawa ke Singapura, Palembang dan Pontianak. Mereka juga memperniagakan pil kuini sebagai dagangan seludup kerana tidak mempunyai dokumen urus niaga yang sah. Pil kuini amat penting pada waktu itu memandangkan penyakit malaria sering menyerang Kepulauan Melayu pada ketika itu. Urus niaga berkaitan pil ini tergambar dalam petikan berikut:

“...buat sementara pil kuini kami hanya separuh dijual kepada Then Boo Phun, bukan kepada syarikat dia - Sam Hoy Thung- dengan harga $\$ 1.00$ British Malaya sebutir. Bakinya sebanyak 130,000 butir 
lagi, kami tahan dan itu disimpan dalam bilik aku" (Warna Sukma Usia Muda, hlm. 61).

Dengan perniagaan pil kuini, mereka mendapat keuntungan yang besar dan berlipat ganda. Barangan yang didagangkan di sekitar Kepulauan Melayu turut melibatkan barangan lain seperti dirakamkan dalam petikan ini: "Bugis peladang kelapa dan Madura penternak sapi, tukang gunting, peniaga di pasar. Bugis dan Madura begitu, yang menampung emas daripada pendulang Melayu dan Dayak! Bawa ke mari! Saya beli! (Warna Sukma Usia Muda, hlm. 65). Lakaran yang dipaparkan oleh Arena Wati di atas menunjukkan sebahagian daripada barang-barang penting dan mereka yang terlibat dalam perdagangan di tempat-tempat tertentu. Sementara pergerakan pelayaran perdagangan yang berpusat di Singapura tersebut dapat dilihat dari satu daerah ke daerah yang lain. Dari Singapura, kapal Sukma Bayu yang diterajui Rahim menuju ke Pontianak melalui Pulau Bintan, masuk ke Selat Riau, Tanjung Samak di timur Teluk Klabat di hujung utara Pulau Bangka sebelum memasuki Kuala Kapuas, Pontianak. Mereka sampai ke Pontianak pada hari Rabu, 16 September 1942. Sementara hasil dagangan yang dibawa pada ketika itu adalah "Hanya satu kodi jam Swiss, dan satu kotak berisi 20 bungkus atau 12 batang jarum jahit mesin Singer, satu botol kecil berisi 1000 butir batu api lighter, kami bawa ke Pontianak" (Warna Sukma Usia Muda, hlm. 75).

Dalam hal ini, sumber pensejarahan menyebut bahawa utusan Belanda yang sampai ke kota-kota di sepanjang sungai di Johor dan di Riau berasa kagum dengan kegiatan perdagangan yang ditemui oleh mereka di kota-kota ini. Sesetengah daripada barang-barang yang diperdagangkan ialah emas, kayu gaharu, kelembak, pedro porco, sarang burung, gading, kapur barus, bijih timah, rotan, lilin, lada, garam, beras, tembaga, spiauter, kain sutera putih dari China, tembikar, kuali besi Cina, kain (Guinees, dll), kain merah (laken), benang emas Jepun dan candu" (Leonard Y. Andaya, 1987:51).

Berdasarkan pemaparan Arena Wati dalam karyanya, didapati bahawa faktor keperluan perdagangan telah mewujudkan hubungan antara MelayuBugis di Alam Melayu. Keadaan ini telah membuka peluang bagi rakyat di sesebuah negara, termasuk golongan perantau yang datang khususnya untuk mencari rezeki di negara lain. Hal ini ditambah pula dengan situasi 
kelembapan ekonomi di daerah asal yang menyebabkan penduduknya keluar mencari kehidupan yang lebih baik di tempat baharu. Arena Wati dalam Warna Sukma Usia Muda telah memerihalkan suasana di tempat baharu yang dituju oleh Abdul Rahim dan rakan-rakannya, iaitu di Kota Singapura sebagai pusat perdagangan yang maju dan lebih kondusif pada ketika itu dan di Johor sebagai tempat mereka berasimilasi dengan masyarakat setempat. Penerimaan masyarakat setempat juga menjadi penyebab perantau dapat bertahan lama di tempat baharu. Hakikat yang dipaparkan oleh Arena Wati ini telah diperakui oleh catatan sejarah yang menyebut bahawa orang Minangkabau telah berada di kawasan Alam Melayu ini sejak beberapa kurun lamanya, dan orang Bugis pula telah menetap dengan aman di wilayahwilayah Johor menjelang pertengahan kurun ke tujuh belas (Leonard Y. Andaya, 1987: 21). Pernyataan ini membuktikan bagaimana pengarang Arena Wati menjadikan sejarah sebagai asas dalam pembinaan naratifnya.

Dalam novel Sudara (1994) juga, pengarang memperlihatkan kepakaran orang Makassar dan Bugis dalam bidang perkapalan dan pelayaran yang membawa mereka untuk menerokai lautan bagi kegiatan perdagangan di seluruh Nusantara. Kemahiran dalam membina kapal/ armada dan mengendalikan dunia perkapalan ini amat penting dalam merealisasikan perdagangan di Alam Melayu. Gambaran kemahiran orang Makassar dan Bugis tersebut antaranya dilukiskan oleh pengarang Arena Wati dalam petikan berikut:

"Engku Kelang, ayahanda Raja Nongcik menggunakan orang Makasar dan Bugis bekas pengikut Patappak Daeng Mantek (Daeng Matteko menurut panggilan orang Riau dan Selangor) membina kembali perahu ini jadi bentuk kecil menurut model perahu orang Barat (Sudara, hlm. 158).

Melalui novel Warna Sukma Usia Muda pula, pengarang melukiskan sifat peribadi watak pemuda Bugis yang kental, tabah, enggan bekerjasama dengan pihak penjajah, bersemangat juang dan berwawasan dalam menerokai kejayaan hidup terutama di lautan. Gambaran sifat-sifat peribadi watak utama, iaitu Abdul Rahim dapat dikesan pada petikan berikut: 


\begin{abstract}
"Aku? Dalam umur 17 tahun, sudah diterima dan berperanan secara rasmi, sebagai Pelaut Muda Sulawesi, bergerak di bawah tanah menentang Nippon demi merdeka sejati. Wadah diriku dalam ekonomi? Aku belum kaya. Tetapi aku ada wang. Aku, bukan pelaut yang menggantungkan hidupnya pada upah, tetapi akulah yang mengupah orang" (Warna Sukma Usia Muda, hlm. 69).
\end{abstract}

Petikan ini bukan sahaja memberikan latar belakang awal tokoh perantau yang dijadikan sebagai objek utama penceritaan pengarang dalam novel ini, malah menggambarkan ciri-ciri peribadinya sebagai susuk anak muda yang bersemangat dan bercita-cita tinggi untuk menggapai wawasan peribadinya. Keupayaan pemuda Bugis ini sebagai pelaut dan pedagang yang bukan sahaja berupaya untuk menyara keperluan diri dan keluarga sendiri, sebaliknya "akulah yang mengupah orang." Frasa ini menjelaskan makna kejayaan atau pencapaian yang diperoleh Abdul Rahim dalam perdagangan sehingga beliau mampu menjadi seorang tauke atau majikan kepada orang lain.

Semangat dan dorongan daripada diri sendiri yang menjadi tunjang utama pergerakannya ke daerah baharu, selain dorongan kuat keluarganya dalam memenuhi cita-cita untuk meneruskan pelajarannya, sekali gus berjaya dalam pelayaran dan peniagaan yang diwarisi daripada keturunan datuk dan ayahnya di Makassar. Apatah lagi beliau merupakan anak lelaki sulung dalam keluarganya (anak sulung sebenarnya meninggal dunia sejak kecil). Dengan perkataan lain, kemahiran orang Bugis dalam pelayaran dan perdagangan telah membawa mereka ke seluruh Nusantara termasuk ke Tanah Melayu yang seterusnya menjalinkan hubungan perdagangan dengan masyarakat tempatan termasuk orang Melayu.

Berdasarkan teks yang diteliti, pengarang menunjukkan bahawa untuk berjaya menjadi seorang pedagang, bukanlah sesuatu yang mudah. Hal ini dapat ditelusuri melalui cabaran yang dihadapi oleh mereka. Misalnya, dalam konteks pelayaran Abdul Rahim, kawasan yang dituju dalam pelayaran awal adalah berjarak jauh, iaitu dari Pulau Jawa menuju ke Semarang, sebelum menuju ke Singapura, Pontianak dan ke tempat-tempat lain. Pergerakannya bermula pada 26 Julai 1942, apabila kapal Sukma Bayu keluar dari Kali Baru menuju ke ke Teluk melalui Selat Makassar, 
Selat Madura, merentasi Laut Jawa antara Tanjung Pangkah di timur dan Selat Sunda di barat. Perjalanan jauh mereka menuju ke Singapura melalui sama ada Selat Gaspar, singgah di Pulau Seliu dan Pulau Kundur sebelum melewati Selat Durian dan masuk ke Selat Singapura. Ia merupakan satu pelayaran yang jauh jaraknya dan mengambil masa berminggu-minggu. Namun, pengarang memperlihatkan bahawa halangan sebenar yang dirempuhi Rahim dan rakan-rakan sekapalnya adalah lebih daripada soal jarak. Mereka terpaksa menghadapi pelbagai halangan dan rintangan, yang terdiri daripada bencana teknologi pemusnah manusia yang memusnahkan benda dan manusia dalam perang, iaitu bom periuk api. Gambaran tersebut dilukiskan oleh pengarang melalui petikan berikut:

"Bahaya dalam pelayaran yang mengancam kami ketika itu ialah periuk api di Laut Jawa, di kawasan Ujung Pangkah, di luar muara Begawan Solo di pantai utara Jawa Timur, masuk ke Selat Madura hingga ke Selat Bali; di kawasan Selat Sunda, di perairan Selat Bangka, Perairan Kepulauan Riau hingga ke Selat Melaka" (2010: 73).

Pengarang juga memaparkan bahawa bukan sahaja puluhan, malah ratusan perahu layar orang Makassar dan Bugis yang menjadi mangsa periuk api peninggalan Belanda dan Inggeris di lautan. Bom periuk api ditabur oleh pihak kolonial Belanda di seluruh Laut Jawa dan di sekitar Kepulauan Riau. Bom periuk api turut ditabur oleh British di seluruh Selat Melaka dan di sepanjang Selat Singapura. Kedua, bencana daripada alam seperti terumbu karang, di antara Kepulauan Bulan dan Singapura, sama ada terumbu karang yang terdedah di permukaan laut atau di dalam laut yang tidak sampai dua meter dalamnya. Ketiga ialah serangan daripada bajak laut (lanun) yang sentiasa bermaharajalela mengganggu dan merampas barang dagangan pelayar di sekitar kepulauan. Keempat, ialah ancaman serangan torpedo dari kapal selam Tentera Bersekutu, terutama di Selat Melaka, Selat Sunda, Selat Karimata (di perairan Kalimantan Barat) dan Laut Natuna serta di Laut Jawa sendiri. Kesemua bentuk halangan tersebut harus dilalui dan dihadapi oleh kebanyakan kapal yang belayar di lautan, termasuk kapal yang dikendalikan oleh Rahim.

Perbincangan di atas memperlihatkan faktor peribadi pada individu yang terlibat dengan pelayaran dan perdagangan. Keazaman dan 
kesungguhan Rahim menjadi salah satu faktor yang mendorong pelayaran dan perdagangannya. Apatah lagi aktiviti pelayaran merupakan satu kelebihan dan kehebatan bagi orang Bugis secara turun-temurun. Sebagai masyarakat yang mempunyai kehandalan dalam ilmu pelayaran, masyarakat Bugis dapat bergerak ke seluruh rantau Asia. Dalam konteks ini, Christian Pelras merujuk mereka sebagai "they are among the most fascinating peoples of maritime Southeast Asia.” Pernyataan oleh pengkaji Bugis yang terkenal ini didapati berupaya menyokong kebenaran paparan Arena Wati melalui karya-karyanya tentang dunia pelayaran orang Bugis dan hubungannya dengan masyarakat di alam Melayu.

\section{Hubungan Perkahwinan}

Hubungan kekeluargaan atau persaudaraan melalui perkahwinan antara orang Melayu dan Bugis dipaparkan melalui salasilah percampuran keturunan. Perkahwinan lima bersaudara Bugis dengan kerabat diraja Johor telah mengukuhkan lagi pengaruh dalam institusi kekeluargaan dan seterusnya peranan orang Bugis dalam politik dan pentadbiran Johor. Misalnya, perkahwinan antara Daeng Parani dengan Tengku Tengah/ Tengku Irang (kakak Tengku Mandak), iaitu saudara Sultan Sulaiman di Johor. Setelah pertabalan Sultan Sulaiman sebagai Sultan Johor, berlaku perkahwinan beramai-ramai antara lima bersaudara Bugis dengan kaum kerabat diraja tempatan. Sebagai contoh, Daeng Merewah iaitu Yamtuan Muda Johor pertama dikahwinkan dengan Tun Encik Ayu, anak Temenggung Abd al-Jamal di Johor, manakala Daeng Chelak Yang Dipertuan Muda yang kedua berkahwin dengan Tengku Mandak, anak Sultan Abd al-Jalil IV, iaitu saudara perempuan Sultan Sulaiman (V.M Hooker, 1991:157).

Dengan pertolongan dalam mengalahkan musuh yang diberikan, membolehkan orang Bugis bertapak di Selangor. Sebelum ke Johor, sebenarnya orang Bugis telah mula bertapak di Selangor dan terlibat dalam banyak aktiviti peperangan dalam usaha mencari jalan untuk mengukuhkan kedudukan mereka di setiap tempat yang didatangi. Upu Daeng Parani misalnya, berkahwin pula dengan anak Yamtuan Selangor. Melalui perkahwinan tersebut, proses sosialisasi dan asimilasi MelayuBugis berlangsung. Proses sosialisasi dan asimilasi juga telah memberi 
kesan kepada perubahan-perubahan sosial tertentu. Misalnya gelaran 'Opu' ditukar kepada 'Raja', di samping berlakunya perubahan pada bahasa Melayu, percampuran adat istiadat dan seni budaya dalam masyarakat tersebut. Melalui novel Rindu Aroma Padi Bunting (2012), Arena Wati menjadikan sejarah tersebut sebagai asas dalam pembinaan naratifnya. Melalui penulisannya, pengarang memaparkan bagaimana kesinambungan sejarah hubungan Melayu-Bugis yang berlangsung sejak sekian lama melalui perkahwinan. Hal ini digambarkan melalui hubungan percintaan dan seterusnya perkahwinan dengan gadis bernama Mayang Cilalang Daeng Bulaeng dari Gowa, Makassar dengan Raja Nasrun dari Selangor, seperti yang dipaparkan dalam petikan ini:

"Kerana itu, maka keluarga dari Gowa, mengharap sangat, agar sekembalinya Daeng Bulaeng dari Holland, dia mesti cepat pergi menabur bunga atas kubur semoga mampu melembutkan kembali hati keluarga di Maros, dan orang di Maros itu bermaksud ikhlas, melepaskan Mayang Cilallang Daeng Bulaeng berjodoh dengan Raja Nasrun dari Selangor, di Malaya itu." (Rindu Aroma Padi Bunting, hlm. 10).

"Gambar itu perlu sebagai kenangan abadi pertemuan semua sekeluarga dengan Selangor-Johor." "Bagus juga!” Karaeng Sunggu tergelak. "Enci Saleh mahu begitu. Dia bilang peristiwa malam ini, bukan hanya proses urusan perkahwinan biasa, tapi ada yang terpenting, iaitu simbol dalam sejarah pertemuan kembali MakasarGowa dari Makasar, dengan Selangor-Johor dari Malaya. Semua setuju, dan terharu." (Rindu Aroma Padi Bunting, hlm. 79).

Menerusi kedua-dua petikan di atas, jelas menunjukkan bagaimana institusi perkahwinan berfungsi sebagai jambatan yang menghubung dan menyatukan antara dua saudara serumpun ke dalam ikatan rantaian kekeluargaan yang lebih utuh dan berpanjangan. Ikatan tersebut menjadi lebih teguh dan bermakna apabila digambarkan betapa kedua-dua belah pihak daripada kedua-dua keluarga dari dua negara saling menghormati dan menyanjungi sesama mereka. Hubungan kekeluargaan yang terhasil daripada perkahwinan tersebut berlanjutan sehingga hari ini, malah sebahagian daripada masyarakat berketurunan Bugis telah menjadi orang penting di Malaysia. 


\section{Hubungan Sosiobudaya}

Selain hubungan yang terjalin melalui faktor ekonomi, hubungan MelayuBugis juga terbentuk pada faktor sosiobudaya. Aspek sosiobudaya itu secara luas boleh dilihat antaranya melalui pemikiran atau idea - ilmu pengetahuan, bahasa, falsafah, persuratan, mitos, legenda, kesusasteraan, kepercayaan dan cerita-cerita lisan, kebendaaan - iaitu seni bina, bangunan, alat-alat-alat mesin, object of art, pakaian, makanan ubat-ubatan dan perabot, kesenian - dilihat dari dua bidang kemahiran, iaitu seni lakon (teater, tarian, muzik, nyanyian) dan seni tampak (ukiran, lukisan, seni pahat, tenunan, takat dan anyaman), serta nilai dan norma yang merangkumi peraturan, undangundang, adat resam, gaya perlakuan, pantang larang, upacara dan nilai-nilai keagamaan. Hubungan kekeluargaan misalnya, didapati sering menjadi batu loncatan dalam kalangan kedua-dua kaum untuk berhijrah ke sesuatu tempat baharu. Hubungan kekeluargaan yang terbentuk sebelumnya seolah-olah membentuk satu rangkaian yang memudahkan kedatangan atau pemergian mereka ke tempat baharu. Situasi perpaduan dan keakraban hubungan antara sesama Melayu di seluruh Nusantara, terutama dalam konteks sosiobudaya diperlihatkan sebagai amat kuat dan utuh atas dasar keserumpunan. Semua itu terbentuk berpaksikan tiga asas utama, iaitu bangsa, agama dan budaya seperti yang digambarkan oleh Arena Wati;

\footnotetext{
"Kita sebangsa Melayu, walaupun masing-masing bersuku lain," kata Palurang Daeng Alle. "Campa, Kemboja, Patani, Makasar; seluruhnya suku-suku Melayu. Kita semua seindung-kandung budaya kemelayuan, dan itulah induk kebangsaan kita. Kesukuan kita dalam kebangsaan Melayu itu diikat pula oleh agama kita yang sama" (Sudara, hlm. 326).
}

Melalui petikan di atas, pengarang menegaskan bahawa kita semua adalah bersaudara dengan berkongsi nilai-nilai budaya, adat istiadat dan yang paling penting ialah agama. Melalui novel Warna Sukma Usia Muda pula, pengarang turut menggambarkan suasana penerimaan keluarga angkat Abdul Rahim di Singapura. Di Singapura, Rahim ditempatkan di rumah saudagar Cina bernama Then Boo Phun pemilik Syarikat Sam Hoy Thung yang terkemuka di Singapura. Saudagar Cina tersebut merupakan kawan 
baik, sekali gus rakan kongsi datuknya, Nakhoda Abdul Fatta Daeng. Beliau memperkenalkan Abdul Rahim kepada keluarganya sebagai berikut;

"Ini cucu Daeng Magassing, putera kedua Daerng Mattarang. Sekarang, jadi anak aku selama berada di Singapura. Nah, ini hadiah aku kepadamu, sebagai pengganti Acheng. Ambillah dia jadi anakmu jaga makanannya sebagaimana kau menjaga makanan Daeng Mattarang dulu, menurut makanan orang Islam" (Warna Sukma Usia Muda, hlm. 58).

Melalui teks Warna Sukma Usia Muda pengarang menunjukkan walaupun Then Boo Phun sekeluarga adalah berbangsa Cina dan bukan beragama Islam, kefahaman mereka terhadap sosiobudaya orang MelayuIslam begitu terserlah. Rahim dilayan seperti ahli keluarga mereka sendiri, diberi ibu angkat yang menguruskan makan minumnya mengikut Islam. Di sanalah Rahim mendapat asuhan dan kasih sayang menggantikan kasih sayang kedua ibu bapanya yang jauh ditinggalkan di Makassar. Begitu juga apabila beliau berada di Benut, Johor dan Pontianak. Di kebanyakan tempat tersebut, beliau diterima dengan baik oleh individu yang didatangi dari kelompok masyarakatnya. Hakikat ini berlangsung secara lancar, memandangkan keadaan sosiobudaya yang hampir sama dan kondusif di tempat yang dituju merupakan salah satu faktor yang mempengaruhi kesediaan seseorang perantau untuk kekal lama di perantauan dan kejayaannya di perantauan. Dalam konteks ini, ia berkaitan dengan hubungan kekeluargaan yang wujud di tempat baharu, yang menjadi salah satu faktor yang berkait rapat.

Hubungan berasaskan kekeluargaan dan persamaan nilai-nilai sosiobudaya banyak dipaparkan menerusi novel-novel Arena Wati, yang kebanyakannya bertitik tolak pada asas dan nilai-nilai kebudayaan yang dimiliki bersama. Melalui Sudara misalnya, diperlihatkan bagaimana caranya Raja Hamidah di Malaysia menyambut kehadiran tetamu yang juga ahli keluarganya dari Makassar yang diperkenalkan kepadanya dengan penuh adat, adab dan tertib seperti sebagaimana yang diasuh ibunya petikan berikut:

\footnotetext{
"Ini nenekmu, nak," kata Dr. Raja Hamisah. "Gowari Karaeng Lukluk." Raja Hamisah perkenalkan sebagaimana yang dia tahu daripada pegawai kedutaan tadi. Usia wanita itu sudah 81 tahun.
} 
Bekas pejuang politik sebelum Perang Dunia Kedua, dan pejuang dalam perang revolusi tahun 1940-an. Raja Hamidah memeluk wanita yang sudah terlalu tua itu, dan tanpa kata dia cium kedua-dua belah pipinya. Karaeng Lukluk menyapu-nyapu kepala Raja Hamidah. Dan Raja Hamisah bangkit, dan membawa anaknya kepada seorang wanita tua usia 58 tahun, pesara doktor bedah. "Ini mak longmu. Bulaeng Karaeng Tiknok” (Sudara, hlm. 416).

Selain daripada itu, faktor persamaan sosiobudaya antara tempat asal dengan tempat tujuan mereka akan selamanya didapati menjadi daya tarikan untuk mereka datang ke negara serumpun. Persamaan tersebut antara lain dapat dikesan pada aspek bahasa, agama dan nilai-nilai sosiobudaya serumpun yang dikongsi oleh Rahim dengan penduduk di Kepulauan Melayu. Dengan adanya persamaan ciri-ciri ini, maka proses untuk menyesuaikan diri akan berjalan dengan lancar. Keupayaan mereka menyesuaikan diri dengan kehidupan di daerah atau negara lain membolehkan mereka bukan sahaja mengekalkan dan mempertahankan kedudukan mereka di daerah baharu, malah mencipta kejayaan dalam kehidupan yang lebih baik.

\section{PENUTUP}

Hubungan Melayu-Bugis yang banyak dipaparkan dalam penulisan pensejarahan telah menjadi asas dalam pembinaan naratif novel-novel Sasterawan Negara Arena Wati. Novel-novel yang dipilih dan diperkatakan di sini seperti Sandera (1974), Sudara (1994), Warna Sukma Usia Muda (2005), Rindu Aroma Padi Bunting (2012) dan lain-lain lagi banyak mengangkat tema dan persoalan berkaitan hubungan Melayu dan Bugis. Hubungan tersebut diperlihatkan daripada beberapa perspektif seperti hubungan politik, hubungan perdagangan, hubungan perkahwinan dan hubungan sosiobudaya. Melalui perspektif hubungan politik misalnya, pengarang membincangkan tentang campur tangan orang Bugis dalam pergolakan politik Melayu, dan peranan mereka terhadap suasana kestabilan politik semasa pada ketika itu, telah memberikan mereka kedudukan penting dalam politik zaman tersebut. 
Gambaran tentang hubungan yang terjalin melalui kegiatan perdagangan pula menyerlahkan tahap keupayaan dan kemahiran orang Bugis dalam perniagaan di alam Melayu. Dengan barang dagangan yang pelbagai, mereka merentasi pelbagai cabaran di lautan menuju ke seluruh negeri di Nusantara, termasuk ke Tanah Melayu. Kegiatan perdagangan dan pelayaran yang sinonim dengan masyarakat Bugis mendekatkan mereka dengan penduduk tempatan di negeri mana pun tempat mereka pergi atau singgah, sekali gus mewujudkan kerjasama dan perpaduan antara mereka dengan masyarakat lain di Nusantara, khususnya dengan penduduk di Tanah Melayu. Malah, dalam naratifnya juga pengarang menunjukkan bahawa melalui institusi perkahwinan, hubungan tersebut menjadi semakin teguh dan mantap. Hubungan perkahwinan yang terjalin semenjak awal penglibatan orang Bugis dalam politik di negeri Melayu menjadi begitu signifikan dan memberi implikasi yang besar terhadap demografi masyarakat Melayu pada hari ini. Semua itu menjadikan ikatan antara dua negara serumpun ini begitu erat, umpama tali tersimpul mati. Sementelah pula kedua-duanya, iaitu Melayu dan Bugis memiliki dan berkongsi nilai-nilai sosiobudaya yang menyeluruh dalam hampir setiap entiti kehidupan. Kesemua aspek tersebut jelas dirungkai dalam novel-novel Arena Wati yang telah menjadikan sejarah hubungan Melayu-Bugis sebagai asas pembinaan naratifnya.

\section{NOTA}

${ }^{1}$ Orang Bugis atau dikenali dengan nama tougi terdiri daripada Bone, Wajo, Soppeng dan Barangnipa berasal dari tanah Selatan Sulawesi. Namun, penghijrahan orang Bugis juga disertai oleh orang Mengkassar (tomengkasar) yang terdiri daripada Tombolo, Goa dan Takalara. Istilah Daeng digunakan dalam suku tougi merupakan istilah dari kelompok Mengkassar. Kedua-dua suku ini berasimilasi menjadi Bugis-Mengkassar. Oleh itu, suku bangsa Sulawesi yang berhijrah dan terlibat dalam politik di alam Melayu dikatakan dari suku Bugis-Mengkassar, iaitu gabungan antara suku tougi dan tomengkassar. Lihat Norhalim Hj. Ibrahim, 1998. Sejarah Linggi: Pintu Gerbang Sejarah Pembangunan Negeri Sembilan. Shah Alam: Penerbit Fajar Bakti Sdn. Bhd., hlm. 28 - 30.

${ }^{2}$ Menurut Andaya, Bugis Wajo merupakan suku Bugis yang banyak berhijrah dari Sulawesi ke alam Melayu dan pengaruh serta penguasaan Bugis ini diperkuatkan dengan kedatangan golongan bangsawan Bugis lima bersaudara, yang terdiri daripada Opu Daeng Parani, Opu Daeng Merewah, Opu Daeng Chelak, Opu Daeng Menambun dna Opu Daeng Kemasi. Lihat Shaharom Husain, 1995. Sejarah Johor: Kaitannya dengan Negeri Melayu, Kuala Lumpur: Penerbit Fajar Bakti Sdn. Bhd. hlm. 29.

${ }^{3}$ Dari sudut etimologi, istilah politik berasal daripada perkataan Greek, iaitu 'polis' yang bermaksud 'bahagian' atau unit (city state) persatuan politik yang pernah dibincangkan oleh Plato dan Aristotle, dua orang ahli falsafah Greek yang terkenal. Konsep ini kemudian dikembangkan dan saling berkaitan dengan soal undang-undang, parlimen dan sebagainya. Robert North dan Ruth Murphy (dlm. Maurice Duverger, 1967:11) mentakrifkan politik dalam konteks yang umum, iaitu "the art and practice of 
goverment of human societies." Kamus Dewan (1993:977) juga memberi takrifan bersifat umum apabila menyebut politik sebagai ilmu (pengetahuan) berkenaan cara pemerintahan dan lain-lain, ilmu siasah, ilmu kenegaraan, politik juga berkait dengan segala sesuatu yang berkenaan pemerintahan sesebuah negara atau hubungannya dengan negara lain. Max Weber (dlm. Ilse Dronberger, 1971:280) menjelaskan politik adalah merujuk pada "usaha atau perjuangan untuk berkongsi kuasa (power) atau usaha untuk mempengaruhi pengagihan atau pembahagian kuasa, sama ada di dalam negara atau kumpulan dalam negara." Dalam konteks ini, Weber cenderung memperlihatkan takrif yang lebih khusus, iaitu perkaitan antara politik dengan kuasa kerajaan.

4 'Caping' adalah lambang kesucian wanita kerana wanita adalah sumber zuriat Pembina tamadun (1994:11). Caping yang diperbuat daripada logam dipanggil 'selaka.'

\section{RUJUKAN}

Abdullah bin Abdul Kadir. (1969). The Hikayat Abdullah: The autobiography of Abdullah bin Abdul Kadir (1797-1854). Singapore: Oxford University Press.

Andaya, Leonard Y. (1987). Kerajaan Johor 1641-1728: Pembangunan ekonomi dan politik. Kuala Lumpur: Dewan Bahasa dan Pustaka.

Andi Ima Kesuma. (2004). Migrasi dan orang Bugis. Yogyakarta: Penerbit Ombak.

Arena Wati. (1971). Sandera. Kuala Lumpur: Dewan Bahasa dan Pustaka.

Arena Wati. (1994). Sudara. Kuala Lumpur: Dewan Bahasa dan Pustaka.

Arena Wati. (2005). Warna sukma usia muda. Bangi: Penerbit Universiti Kebangsaan Malaysia.

Arena Wati. (2010). Memoir Arena Wati: Enda Gulingku. Bangi: Penerbit Universiti Kebangsaan Malaysia.

Arena Wati. (2012). Rindu aroma padi bunting. Kuala Lumpur: Dewan Bahasa dan Pustaka.

Carr E.H. (1965). What is history. London: Pelicon Book.

Collingwood R.G. (1966). The idea of history. London: Oxford University Press.

Dr. Tengku Iskandar. (1984). Kamus Dewan Edisi Kedua. Kuala Lumpur: Dewan Bahasa dan Pustaka.

Drs. Sidi Gazalba. (1966). Pengantar sejarah sebagai ilmu. Jakarta: Penerbit Bhratara.

Joseph Chin Yong Liow. (2005). The Politics of Indonesia-Malaysia relations. New York: Routledge.

Kamus Bahasa Melayu Nusantara. (2003). Seri Begawan: Dewan Bahasa dan Pustaka Brunei.

Kamus Besar Bahasa Indonesia. (1988). Jakarta: Departemen Pendidikan dan Kebudayaan Republik Indonesia.

M. Arif Nasution. (2002). Orang Indonesia di Malaysia: Menjual kemiskinan membangun identitas. Yogyakarta: Pustaka Pelajar.

Mohd Yusof Hasan. (1991). Dunia Melayu. Kuala Lumpur: Dewan Bahasa dan Pustaka. 
Muhd.Yusof Ibrahim. (1986). Pengertian sejarah. Kuala Lumpur: Dewan Bahasa dan Pustaka.

Muhd. Yusof Ibrahim. (1997). Ilmu sejarah, falsafah, pengertian dan kaedah. Kuala Lumpur: Dewan Bahasa dan Pustaka.

Norhalim Hj. Ibrahim. (1998). Sejarah Linggi: Pintu gerbang sejarah pembangunan negeri Sembilan. Shah Alam: Penerbit Fajar Bakti Sdn. Bhd.

Pelras, Christian. (1997). The Bugis. United State: Blackwell Publishing.

Shaharom Husain. (1995). Sejarah Johor: Kaitannya dengan negeri Melayu. Kuala Lumpur: Penerbit Fajar Bakti Sdn. Bhd. 
